\title{
PENGARUH SOCIAL LEISURE ACTIVITY TERHADAP PENURUNAN RISIKO WANDERING PADA LANSIA DEMENSIA DI RSJ Dr. RADJIMAN WEDIODININGRAT LAWANG MALANG
}

\section{The Effect of Social Leisure Activity for Decreased Risk of Wandering on Dementia Elderly in Mental Health Hospital Dr. Radjiman Wediodiningrat Lawang Malang}

\author{
Amalia Kusumaningsih $^{1}$, Ah Yusuf ${ }^{2}$, AV Sri Suhardiningsih ${ }^{3}$
}

1. Master Student in Nursing, Faculty of Nursing, UniversitasAirlangga Surabaya, Indonesia

2. Department of Nursing, Faculty of Nursing, Universitas Airlangga Surabaya, Indonesia

3. Departement of Nursing, STIKES Hang Tuah Surabaya, Indonesia

Riwayat artikel

Diajukan: 15 Juli 2019

Diterima: 28 Maret 2020

Penulis Korespondensi:

- Amalia Kusumaningsih

- Universitas Airlangga

Surabaya

amalia.kusumaningsih2017@fkp.unair.ac.id

Kata Kunci:

Social leisure activity, wandering, dementia, elderly
Abstrak

Pendahuluan: Demensia merupakan sebuah sindrom klinis kemunduran fungsi kognitif. Demensia dapat memberikan dampak yang besar baik bagi klien maupun caregiver, salah satunya adalah perilaku wandering. Tujuan penelitian ini untuk mengetahui pengaruh Sosial Leisure Activity dalam menurunkan risiko wanderin. Metode: Desain penelitian ini adalah quasy experimental dengan pre-post test one group. Populasi penelitian 47 lansia dan sampel 34 lansia demensia beserta caregivernya yang berobat jalan di klinik Psikogeriatri RSJ Dr. Radjiman Wediodiningrat Lawang. Teknik sampling dengan metode purposive sampling. Variabel dalam penelitian ini adalah Sosial Leisure Activity dan risiko wandering. Instrumen yang digunakan adalah Skrining Elopement, Indeks Kemandirian KATZ, den kuesioner Training Pada Caregiver. Intervensi dilakukan di rumah oleh caregiver berupa serangkaian aktivitas yang dilakukan selama 4 minggu dengan frekuensi 3 kali seminggu dan 45 menit tiap aktivitas. Data dianalisis menggunakan Paired Samples T-Test. Hasil: Hasil analisis menunjukkan ada perbedaan signifikan $(p=0,000)$ pada nilai risiko wandering sebelum dan sesudah dilakukan intervensi. Data pelatihan pada caregiver memberikan hasil ada perbedaan yang signifikan $(p=0,000)$ pada pengetahuan caregiver sebelum dan sesudah diberikan pelatihan. Discussion: Risiko wandering pada lansia demensia dapat diturunkan dengan memberikan aktifitas fisik secara rutin yang mengedepankan unsur interaksi social. Sosial Leisure Activity merupakan aktifitas yang efektif untuk dikembangkan karena mudah dilaksanakan dan efisien karena tidak membutuhkan biaya yang tinggi.

\section{Abstract}

Introduction: Dementia is a clinical syndrome of cognitive decline. Dementia can have a great impact on both clients and caregivers, one of which is wandering behavior. The purpose of this study was to determine the effect of Social Leisure Activity in reducing the risk of wanderin. Method: The design of this study was quasy experimental with one group pre-post test. The study population was 47 elderly and a sample of 34 elderly with dementia and their caregivers who went outpatient at the Psychogeriatric Clinic of RSJ Dr. Radjiman Wediodiningrat Lawang. Sampling technique with a purposive sampling method. The variables in this study are Social Leisure Activity and risk of wandering. The instrument used was Elopement Screening, KATZ Independence Index, and Training At Caregiver questionnaire. The intervention was carried out at home by the caregiver in the form of a series of activities carried out for 4 weeks with a 
frequency of 3 times a week and 45 minutes for each activity. Data were analyzed using Paired Samples T-Test. Results: The analysis showed that there was a significant difference $(p=0,000)$ in the value of risk wandering before and after the intervention. Training data on caregivers gave a significant difference ( $p=$ 0,000) in caregiver knowledge before and after training. Discussion: The risk of wandering in elderly people with dementia can be reduced by providing regular physical activity that emphasizes the element of social interaction. Social Leisure Activity is an effective activity to develop because it is easy to implement and efficient because it does not require high costs.

\section{PENDAHULUAN}

Demensia merupakan suatu sindrome klinis berupa penurunan daya ingat, kemampuan berbahasa dan berkomunikasi, kemampuan pengambilan keputusan dan penilaian, pengelolaan keuangan, dan disorientasi, bingung, serta mudah ansietas dan bila berlanjut dapat menjadi wandering (Brittain et al., 2017), kemunduran progresif fungsi kognitif dan kemampuan melaksanakan ADL secara mandiri (Prince, M., Wimo, A., Guerchet, M., Ali, G., Wu, Y. \& Prina, 2015). Demensia dengan gejala neuropsikiatrinya dapat memberikan dampak yang sangat merugikan salah satunya perilaku wandering. Wandering memberikan dampak yang kompleks, menantang dan berpotensi berbahaya pada klien demensia, gangguan perilaku, lari dari perawatan, cedera, dan bahkan kematian (Kwak, Yang and Koo, 2015). Dampak dari perilaku wandering yang sangat merugikan tersebut dapat berpengaruh terhadap tingkat mortalitas pada populasi lansia pada umumnya dan lansia demensia khususnya (Algase, 1998). Penderita demensia yang wandering sangat rentan mengalami gangguan interaksi disebabkan karena adanya penurunan fungsi kognitif yang menyulitkan bagi penderita dan orang sekitarnya untuk melakukan komunikasi dengan baik. Penderita demensia yang mengalami wandering lebih sering didapatkan kejadian hilang karena adanya gangguan interaksi pada penderita (Barnard-Brak, Richman, and Owen, 2018). Perilaku wandering biasanya disebabkan oleh suatu kondisi yang tidak nyaman dan terjadi dalam waktu yang cukup lama.

Populasi lansia demensia di dunia sejumlah 47,6 juta jiwa dan diperkirakan jumlahnya meningkat 7,7 juta jiwa per tahun (Olley and Morales, 2018), meningkat tiga kali lipat pada tahun 2050 (Baumgart et al., 2015). Alzheimer Australia (2011) melakukan studi mencatat bahwa 1800 kasus demensia baru ditegakkan tiap minggunya (MacAndrew et al., 2017). Menurut DY. Suharya (2017) direktur regional Azheimer Asia Pasifik memperkirakan jumlah lansia demensia di Indonesia pada tahun 2017 sebanyak 1,2 juta jiwa, setiap tiga detik terdapat satu orang terdiagnosis demensia (Republika, 2017). Populasi demensia yang meningkat tersebut tentu disertai juga dengan peningkatan perilaku wandering.Studicross-sectional di Netherland mencatat rata-rata kejadian wandering sekitar $15 \%-28 \%$ terjadi di nursing home dan atau fasilitas kesehatan lainnya, kejadian perilaku wandering pada klien demensia sebanyak 80\% (Volicer, Van Der Steen and Frijters, 2013). Studi di Texas Amerika Serikat menyebutkan satu dari lima penderita demensia mengalami wandering dan $40 \%$ nya hilang, tersesat, dan membutuhkan bantuan untuk pulang (Barnard-Brak, Richman and Owen, 2018). Intervensi untuk mencegah wandering masih perlu ditingkatkan. Penanganan penderita demensia dan wandering dengan metode tradisional adalah dengan memberikan restraint dan atau terapi neuroleptik (Qiang, Weichao, and Weilan, 2018). Metode tradisional tersebut masih sangat jauh dari efektif karena memberikan efek samping yang lebih besar (Volicer, Van Der Steen and Frijters, 2013). Klien demensia yang belum jatuh dalam kondisi wandering akan lebih baik diberikan intervensi untuk pencegahannya. Intervensi yang bisa diberikan untuk menurunkan wandering adalah dengan memberikan leisure activity yang berupa kegiatan berjalan-jalan di lingkungan sekitar, berkebun (Zhang et al., 2017), menonton televisi atau video, dan mendengarkan musik (Moyle et al., 2018). Leisure activity pada klien demensia harus disesuaikan dengan kebutuhan klien, dimana kegiatan yang diberikan harus berfokus pada penatalaksanaan afektif (perasaan) klien, 
dengan harapan hal tersebut pada akhirnya akan mempengaruhi kognitif klien (Reynolds, 2010). Klien demensiayang berusaha menjaga perasaannya tetap dalam kondisi yang baik maka dibutuhkan dukungan sosial baik dari keluarga, teman maupun lingkungannya (Gagliardi et al., 2010). Dukungan sosial yang digabungkandenganleisure activity dapat disebut dengan Social Leisure Activity.

Penelitian pada kasus demensia telah banyak dilakukan, tetapi penelitian untuk kasus wandering masih sangat jarang dilakukan. Demikian juga dengan penelitian tentang intervensi alternative untuk lansia demensia yang wandering. Tujuan dari penelitian ini adalah untuk menganalisis pengaruh social leisure activity terhadap penurunan risiko wandering pada lansia demensia.

\section{METODE}

Desain penelitian ini adalah quasy experimental dengan pre-post test one group. Sampel dalam penelitian ini adalah lansia demensia beserta caregivernya yang melakukan rawat jalan di Klinik Psikogeriatri RSJ Dr. Radjiman Wediodiningrat Lawang Malang, dengan besar sampel sebanyak 34 orang. Teknik sampling yang digunakan adalah metode purposive sapling. Responden dalam penelitian ini ditentukan berdasarkan criteria inklusi dan criteria eksklusi yang masing-masing dibagi menjadi criteria untuk lansia dan criteria untuk caregiver. Kriteria inklusi untuk lansia meliputi lansia demensia ringan hingga sedang, berusia 60-75 tahun, tinggal bersama keluarga atau caregiver, memiliki risiko wandering, mampu melakukan aktivitas fisik secara mandiri. Kriteria inklusi untuk caregiver adalah berusia lebih dari 18 tahun, mampu baca tulis, minimal berpendidikan SMA. Kriteria eksklusi untuk lansia adalah lansia demensia yang tinggal dip anti, mengalami gangguan pendengaran yang berat dan mengalami gangguan penglihatan yang berat. Kriteria eksklusi untuk caregiver meliputi caregiver yang memiliki penyakit kronis yang tidak mampu beraktivitas fisik dan menderita demensia.

Instrumen yang digunakan dalam studi ini adalah Skrining Elopement untuk mengukur variable dependen yaitu risiko wandering yang dikembangkan oleh BarnardBrak (Barnard-Brak, Richman and Owen, 2018). Variabel independent dilakukan berdasarkan odul social leisure activity. Instrumen lain yang digunakan adalah kuesioner pelatihan pada caregiver untuk mengukur tingkat pengetahuan caregiver tentang perilaku wandering dan social leisure activity, serta Indeks Kemandirian KATZ untuk menilai tingkat kemandirian lansia demensia dalam melakukan aktivitas fisik. Analisis yang digunakan adalah Paired Samples T-Test.

Social leisure activity merupakan serangkaian kegiatan yang diberikan untuk mengisi waktu luang lansia demensia. Kegiatan tersebut meliputi menonton video, mendengarkan music, berjalan-jalan di sekitar lingkungan rumah, dan berpartisipasi dalam kegiatan berkebun. Social leisure activity dilaksanakan selama 4 minggu dengan frekuensi 3 kali seminggu dan 45 menit setiap aktivitas. Setelah melakukan aktivitas caregiver diminta mengisi lembar evaluasi setelah melakukan kegiatan.

Penelitian ini telah mendapatkan sertifikat kelayakan etik dari KEPK Fakultas Keperawatan Universitas Airlangga Surabaya dengan nomor 1291-KEPK dan KEPK dari RSJ Dr. Radjiman Wediodiningrat Lawang Malang dengan nomor LB.02.03/XXVII.5.7/3336/2019.

\section{HASIL}

A. Indeks Kemandirian KATZ

Pengukuran instrument Indeks Kemandirian KATZ didapatkan hasil seluruh lansia demensia memiliki kemandirian dalam aktivitas fisik dalam rentang skor 14-16 yang menunjukkan bahwa tingkat kemandirian lansia demensia adalah mandiri dalam melakukan aktivitas fisik.

B. Karakteristik Demografi

Tabel 1 menunjukkan karakteristik responden lansia demensia berdasarkan usia, sebagian besar usia responden adalah 70-75 tahun sebanyak 17 orang $(50,0 \%)$. Jenis kelamin sebagin besar wanita sebanyak 19 orang $(55,9 \%)$. Lama sakit sebagian besar lebih dari 12 bulan sebanyak 23 orang $(67,6 \%)$. Pendidikan responden sebagian besar SLTP sebanyak 13 orang (38,2\%). Keluarga merupakan orang terdekat sebanyak 25 orang $(73,5 \%)$. Jenis dukungan yang diterima oleh responden sebagian besar adalah psikologis sebanyak 24 orang $(70,6 \%)$. Status pekerjaan sebagian besar responden tidak 
bekerja sebanyak 17 orang $(50,0 \%)$. Sumber pendapatan sebagian besar berasal dari pensiunan sebanyak 11 orang $(32,4 \%)$. Status pernikahan sebagian besar adalah duda/janda sebanyak 20 orang $(58,8 \%)$. Status kepemilikan rumah sebagian besar rumah orang tua/keluarga sebanyak 21 orang $(61,8 \%)$. Lansia demensia sebagian besar mengidap penyakit kronis sebanyak 24 orang $(70,6 \%)$. Jenis penyakit yang paling banyak diderita responden adalah Hipertensi sebanyak 10 orang $(29,4 \%)$. Gejala neuropsikiatri yang paling banyak ditemukan pada responden adalah lupa dan bingung sebanyak 17 orang $(50,0 \%)$. Berdasarkan uji ANOVA diketahui bahwa karakteristik usia ( $\mathrm{p}$ value $=$ 0,049 ), lama sakit ( $\mathrm{p}$ value $=0,022$ ), pendidikan ( $\mathrm{p}$ value $=0,041)$, orang terdekat $(\mathrm{p}$ value $=0,015)$, status pekerjaan ( $\mathrm{p}$ value $=0,050)$, status pendapatan ( $\mathrm{p}$ value $=0,020)$, status tempat tinggal $(\mathrm{p}$ value $=0,046)$ menunjukkan bahwa ada hubungan antara karakteristik demografi dengan subjective well-being. Sementara pada gejala neuropsikiatri menunjukkan tidak ada hubungan ( $\mathrm{p}$ value $=0,556$ ) dengan subjective well-being. Uji Independent Samples T-Test untuk karakteristik jenis kelamin, status pernikahan, penyakit kronis, dan jenis dukungan menunjukkan ada hubungan signifikan ( $\mathrm{p}$ value $=$ 0,000 ) dengan subjective well-being.

Tabel 2 menunjukkan karakteristik responden caregiver dimana sebagian besar berusia berusia $31-40$ tahun sebanyak 15 orang $(29,4 \%)$. Jenis kelamin sebagian besar laki-laki sebanyak 18 orang $(26,5 \%)$. Pendidikan sebagian besar caregiver adalah SLTA sebanyak 17 orang $(25,0 \%)$. Pekerjaan sebagian besar adalah swasta sebanyak 14 orang $(20,6 \%)$, sebagian besar menikah sebanyak 25 orang $(36,8 \%)$. Status tempat tinggal sebagian besar adalah rumah milik orang tua sebanyak 18 orang $(26,5 \%)$. Caregiver sebagian besar tidak mengidap penyakit kronis sebanyak 30 orang $(44,1 \%)$.

\section{Training Pada Caregiver}

Berdasarkan tabel 3 nilai minimum sebelum dilakukan pelatihan pada caregiver sebesar 1 dan setelah dilakukan pelatihan pada caregiver naik menjadi 8 , nilai maksimum sebelum dilakukan pelatihan pada caregiver sebesar 7 dan sesudah dilakukan pelatihan pada caregiver naik menjadi 10, nilai total sebelum dilakukan pelatihan pada caregiver 96 dan setelah diberikan pelatihan pada caregiver naik sebesar 321.

\section{Risiko Wandering}

Berdasarkan table 4 nilai mean \pm Sd sebelum perlakuan $21,09 \pm 1,54$ dan sesudah perlakuan $17,44 \pm 2,61$. Kesimpulan dari hasil analisis Paired Samples T-Test adalah terdapat perbedaan yang signifikan $(\mathrm{p}=0,000)$ sebelum dan sesudah dilakukan intervensi. Berdasarkan table 5 menunjukkan distribusi katagori risiko wandering sebelum dilakukan intervensi seluruh $(n=34)$ lansia mengalami risiko wandering. Setelah dilakukan intervensi terdapat perubahan yaitu 21 lansia kondisinya membaik dalam katagori tidak ada risiko wandering, tetapi 13 lansia masih dalam katagori risiko wandering. Berdasarkan table 5 diketahui bahwa item pertanyaan nomor $2,3,9$ memiliki $\mathrm{p}$ value lebih besar dari 0,005 sehingga memberikan arti bahwa tidak ada perbedaan nilai pada pertanyaan tersebut dari sebelum dan sesudah intervensi.

\section{PEMBAHASAN}

Hasil penelitian menunjukkan seluruh klien lansia memiliki risiko wandering sebelum diberikan perlakuan. Nilai tinggi untuk risiko wandering ini terkait pada kondisi lupa waktu, adanya perubahan mood yang mendadak, kehilangan kesabaran, dan suka menyendiri/sendirian. Setelah pemberian intervensi terdapat penurunan risiko wandering pada lansia. Tetapi masih adalansia yang masuk dalam katagori risiko wandering meskipun nilai hasil pengukuran meningkat. Perubahan ini ditunjukkan dengan menurunnya hasil pengukuran semua indikator risiko wandering, yaitu paling banyak pada indikator bicara tidak relevan yang mengalami penurunan terbesar dan indikator lupa waktu mengalami penurunan terkecil. 
Table 1.Karakteristik Demografi Lansia Demensia

\begin{tabular}{|c|c|c|c|c|c|}
\hline \multirow[t]{2}{*}{ Karakteristik responden } & \multicolumn{2}{|c|}{ Kelompok Lansia } & \multirow[t]{2}{*}{ Mean } & \multirow[t]{2}{*}{ Sd } & \multirow[t]{2}{*}{ P Value } \\
\hline & n (34) & $\%$ & & & \\
\hline \multicolumn{6}{|l|}{ Usia } \\
\hline $60-65$ tahun & 10 & 29,4 & & & \\
\hline $66-70$ tahun & 7 & 20,6 & 2,50 & 0,880 & 0,049 \\
\hline $71-75$ tahun & 17 & 50,0 & & & \\
\hline \multicolumn{6}{|l|}{ Jenis Kelamin } \\
\hline Laki-laki & 15 & 44,1 & 1,56 & 0,504 & 0,000 \\
\hline Perempuan & 19 & 55,9 & & & \\
\hline \multicolumn{6}{|l|}{ Lama Sakit } \\
\hline$<6$ bulan & 4 & 11,8 & 2,56 & 0,705 & 0,022 \\
\hline $6-12$ bulan & 7 & 20,6 & & & \\
\hline$>12$ bulan & 23 & 67,6 & & & \\
\hline \multicolumn{6}{|l|}{ Pendidikan } \\
\hline SD & 12 & 35,3 & 2,97 & 0,904 & 0,041 \\
\hline SLTP & 13 & 38,2 & & & \\
\hline SLTA & 7 & 20,6 & & & \\
\hline Sarjana & 2 & 5,9 & & & \\
\hline \multicolumn{6}{|l|}{ Orang Terdekat } \\
\hline Petugas Kesehatan & 3 & 8,8 & 2,09 & 0,514 & 0,015 \\
\hline Keluarga & 25 & 73,5 & & & \\
\hline Pasangan & 6 & 17,6 & & & \\
\hline \multicolumn{6}{|l|}{ Jenis Dukungan } \\
\hline Psikologis & 24 & 70,6 & 2,29 & 0,462 & 0,000 \\
\hline Materi & 10 & 29,4 & & & \\
\hline \multicolumn{6}{|l|}{ Pekerjaan } \\
\hline Tidak bekerja & 17 & 50,0 & 1,71 & 0,799 & 0,050 \\
\hline Bekerja & 10 & 29,4 & & & \\
\hline Pensiunan & 7 & 20,6 & & & \\
\hline \multicolumn{6}{|l|}{ Status Pendapatan } \\
\hline Tidak ada & 8 & 23,5 & & & \\
\hline Gaji tetap & 5 & 14,7 & 2,68 & 1,147 & 0,020 \\
\hline Pensiunan & 11 & 32,4 & & & \\
\hline Keluarga & 10 & 29,4 & & & \\
\hline \multicolumn{6}{|l|}{ Status Pernikahan } \\
\hline Menikah & 14 & 41,2 & 2,59 & 0,500 & 0,000 \\
\hline Duda/Janda & 20 & 58,8 & & & \\
\hline \multicolumn{6}{|l|}{ Status Tempat Tinggal } \\
\hline Rumah Milik Sendiri & 13 & 38,2 & 2,62 & 0,493 & 0,046 \\
\hline Rumah Milik Orang & 21 & 61,76 & & & \\
\hline Tua/keluarga & & & & & \\
\hline \multicolumn{6}{|l|}{ Penyakit Kronis } \\
\hline Ya & 24 & 70,6 & 1,71 & 0,462 & 0,000 \\
\hline Tidak & 10 & 29,4 & & & \\
\hline \multicolumn{6}{|l|}{ Jenis Penyakit } \\
\hline HT & 10 & 29,4 & & & \\
\hline DM & 2 & 5,9 & 1,74 & 1,831 & - \\
\hline Artritis & 3 & 8,8 & & & \\
\hline Hiperkolesterol & 7 & 20,6 & & & \\
\hline Asam Urat & 2 & 5,9 & & & \\
\hline Tidak ada & 10 & 29,4 & & & \\
\hline \multicolumn{6}{|l|}{ Gejala Neuropsikiatrik } \\
\hline Lupa & 6 & 17,6 & & & \\
\hline Lupa dan Bingung & 18 & 52,9 & 5,68 & 2,358 & 0,556 \\
\hline Lupa dan Disorientasi & 4 & 11,8 & & & \\
\hline Lupa dan ansietas & 6 & 17,6 & & & \\
\hline
\end{tabular}


Tabel 2 Karakteristik Demografi Caregiver

\begin{tabular}{|c|c|c|c|}
\hline \multirow[t]{2}{*}{ Karakteristik responden } & \multicolumn{2}{|c|}{ Kelompok caregiver } & \multirow[t]{2}{*}{ Mean } \\
\hline & n (34) & $\%$ & \\
\hline \multicolumn{4}{|l|}{ Usia } \\
\hline $18-30$ tahun & 7 & 13,7 & \multirow{4}{*}{38,765} \\
\hline $31-40$ tahun & 15 & 29,4 & \\
\hline $41-50$ tahun & 7 & 13,7 & \\
\hline $51-60$ tahun & 5 & 9,8 & \\
\hline \multicolumn{4}{|l|}{ Jenis Kelamin } \\
\hline Laki-laki & 18 & 26,5 & \multirow{2}{*}{1,471} \\
\hline Perempuan & 16 & 23,5 & \\
\hline \multicolumn{4}{|l|}{ Pendidikan } \\
\hline SLTA & 17 & 25,0 & \multirow{5}{*}{2,206} \\
\hline D1 & 2 & 2,9 & \\
\hline D3 & 7 & 10,3 & \\
\hline Sarjana & 7 & 10,3 & \\
\hline S2 & 1 & 1,5 & \\
\hline \multicolumn{4}{|l|}{ Pekeriaan } \\
\hline PNS & 3 & 4,4 & \multirow{8}{*}{3,647} \\
\hline Swasta & 14 & 20,6 & \\
\hline Wiraswasta & 4 & 5,9 & \\
\hline Petani & 3 & 4,4 & \\
\hline Pedagang & 2 & 2,9 & \\
\hline Dosen & 1 & 1,5 & \\
\hline Perawat & 3 & 4,4 & \\
\hline Lainnya & 4 & 5,9 & \\
\hline \multicolumn{4}{|l|}{ Status Pernikahan } \\
\hline Lajang & 7 & 10,3 & \multirow{3}{*}{1,853} \\
\hline Menikah & 25 & 36,8 & \\
\hline Duda/Janda & 2 & 2,9 & \\
\hline \multicolumn{4}{|l|}{ Status Tempat Tinggal } \\
\hline Rumah Milik Sendiri & 15 & 22,1 & \multirow{3}{*}{1,618} \\
\hline Rumah Milik Orang Tua & 18 & 26,5 & \\
\hline Lainnya & 1 & 1,5 & \\
\hline \multicolumn{4}{|l|}{ Penyakit Kronis } \\
\hline $\mathrm{Ya}$ & 4 & 5,9 & \multirow{2}{*}{1,118} \\
\hline Tidak & 30 & 44,1 & \\
\hline
\end{tabular}

Tabel 3 Training Pada Caregiver

\begin{tabular}{lccc}
\hline Pengukuran & Pra-tes & Paska-tes & Selisih \\
\hline Minimum & 1 & 8 & 7 \\
\hline Maksimum & 7 & 10 & 3 \\
\hline Sum & 96 & 321 & 225 \\
\hline Mean & 2,8235 & 9,4412 & 6,6177 \\
\hline
\end{tabular}

Tabel 4 Distribusi Nilai Risiko Wandering

\begin{tabular}{|c|c|c|c|c|c|}
\hline & \multicolumn{4}{|c|}{ Risiko Wandering } & \multirow{2}{*}{ p Value } \\
\hline & Mean & SD & Minimum & Maksimum & \\
\hline Pra-tes & 21,09 & 1,54 & 18 & 13 & \multirow[b]{2}{*}{0,000} \\
\hline Paska-tes & 17,44 & 2,61 & 24 & 24 & \\
\hline
\end{tabular}

Tabel 5 Distribusi Katagori Risiko Wandering

\begin{tabular}{|c|c|c|c|}
\hline \multirow{4}{*}{ Prates } & & \multicolumn{2}{|c|}{ Paskates } \\
\hline & & Tidak ada risiko & Ada risiko \\
\hline & $\begin{array}{l}\text { Tidak ada risiko } \\
(\mathrm{n}=0)\end{array}$ & 0 & 0 \\
\hline & $\begin{array}{ll}\begin{array}{l}\text { Ada } \\
(\mathrm{n}=34)\end{array} & \text { risiko }\end{array}$ & $21(61,76 \%)$ & $13(38,24 \%)$ \\
\hline
\end{tabular}


Tabel 6 Hasil Analisis Per Item Srining Elopement

\begin{tabular}{lcccc}
\hline \multirow{2}{*}{ Pertanyaan } & \multicolumn{3}{c}{ Mean } & p Value \\
\cline { 2 - 4 } & Pra-tes & Paska-tes & Selisih & 0,039 \\
\hline $\begin{array}{l}\text { Hilang } \\
\text { Kesabaran }\end{array}$ & 2,5294 & 2,2059 & $-0,3235$ & 0,058 \\
\hline $\begin{array}{l}\text { Suka } \\
\text { Menyendiri }\end{array}$ & 2,2647 & 1,9706 & $-0,2941$ & 0,160 \\
\hline $\begin{array}{l}\text { Tidak respon } \\
\text { komunikasi }\end{array}$ & 2,2059 & 1,9706 & $-0,2353$ & 0,001 \\
\hline $\begin{array}{l}\text { Perubahan } \\
\text { mood }\end{array}$ & 2,5882 & 2,0296 & $-0,5586$ & 0,003 \\
\hline $\begin{array}{l}\text { Kurang } \\
\text { waspada }\end{array}$ & 2,2647 & 1,7941 & $-0,4706$ & 0,000 \\
\hline $\begin{array}{l}\text { Bicara tidak } \\
\text { relevan }\end{array}$ & 2,2647 & 1,4412 & $-0,7647$ & 0,019 \\
\hline $\begin{array}{l}\text { Respon Situasi } \\
\text { baru }\end{array}$ & 2,2059 & 1,8824 & $-0,3235$ & 0,001 \\
\hline $\begin{array}{l}\text { Mudah } \\
\text { tersesat }\end{array}$ & 1,8529 & 1,2941 & $-0,5588$ & 0,422 \\
\hline Lupa waktu & 2,9118 & 1,8529 & $-1,0589$ & \\
\hline
\end{tabular}

Perubahan risiko wandering yang terjadi selain karena intervensi yang diberikan juga dapat dipengaruhi beberapa faktor antara lain: faktor lama sakit, pendidikan lansia dan caregiver, ada tidaknya penyakit kronis pada lansia dan caregiver, status pernikahan lansia dan caregiver, usia caregiver, dan hubungan baik antara lansia dan caregiver. Wimo and Prince, 2010 menemukan bahwa lama sakit lansia demensia meningkatkan beban caregiver dan keluarga yang meliputi beban substansial dan stres psikologis. Lama sakit lebih dari 2 tahun juga merupakan indikator terjadinya risiko depresi dan demensia (Bayu, 2017). Demensia dalam perawatannya menyebabkan beban yang tinggi pada caregivernya karena dibutuhkan tenaga yang besar dalam memberikan perawatan dari hari ke hari serta butuh perhatian yang tinggi, termasuk membantu ADL klien dan menyediakan hal-hal yang berhubungan dengan perawatan klien (Lin et al., 2017).

Wandering sangat berhubungan dengan pengalaman hidup negatif dalam menjalin hubungan dengan keluarga, pasangan, maupun orang lain (MacAndrew, Brooks and Beattie, 2018). Wandering berasal dari pengalaman yang tidak menyenangkan dalam kegiatan seharihari yang kemudian dapat meningkatkan stres caregiver (Volicer, Van Der Steen and Frijters, 2013). Wandering juga menyebabkan peningkatan stress pada caregiver(Volicer, Van Der Steen, and Frijters, 2013). Peningkatan stres pada caregiver berhubungan dengan peningkatan kesulitan dalam mengetahui bagaimana merespon dan menjalin hubungan dengan klien Demensia yang mengalami wandering, kurang istirahat, perilaku yang diulang-ulang, resistensi dan tergantung (Judy, 2017).Riwayat pernikahan yang tidak baik sangat berpengaruh terhadap demensia dan gejala-gejala yang muncul, serta berpengaruh terhadap penatalaksanaan dan perawatan dari caregivernya. Penatalaksanaan demensia sangat berhubungan dengan latar belakang hubungan dengan lingkungan sosial dan riwayat hubungan pribadi atau kehidupan pernikahan yang negatif, serta munculnya perilaku negatif (Ray and Mittelman, 2017). Hubungan yang baik antara caregiver dan lansia dapat meningkatkan adaptasi dari keduanya sehingga mampu memutuskan bentuk aktifitas yang terbaik yang dapat dilakukan (Lau, Chan and Szeto, 2018). Usia caregiver dan pengetahuan caregiver sangat mempengaruhi pemberian perawatan dan menentukan intervensi yang tepat pada demensia (Lau, Chan and Szeto, 2018). Usia yang lebih muda menunjukkan perilaku yang kurang tertarik pada manajemen perawatan dan manajemen intervensi psikososial pada demensia (Moyle et al., 2018). Usia muda tidak mudah menemukan kebutuhan yang sesuai dengan lansia juga berhubungan dengan hal-hal terkait kualitas hidup yang rendah dari lansia dengan demensia, beban keluarga, dan stres caregiver (Traynor et al., 2018). 
Caregiver dengan pemahaman dan pengetahuan yang terbatas tentang kondisi lansia mudah merasa memiliki bebanyang tinggi terutama beban psikologis dan fisik. Setelah diberikan pelatihan tentang social leisure activity, dimana dalam pelatihan juga diberikan penyuluhan tentang demensia, pengetahuan caregiver meningkat dan mulai menyadari bahwa kondisi lansia memang disebabkan karena sakitnya.

Sebuah penelitian yang dilakukan oleh Penrod et al., 2007 menyatakan bahwa sebuah model menyarankan lansia dengan demensia dan caregivernya harus memiliki pendidikan yang memadai untuk dapat memahami perubahan perilaku yang mendadak pada lansia demensia (Ray and Mittelman, 2017). Pengetahuan caregiver sangat berpengaruh pada perawatan dan stres caregiver dalam merawat demensia, peningkatan stres pada caregiver berhubungan dengan peningkatan kesulitan dalam mengetahui bagaimana merespon dan menjalin hubungan dengan klien Demensia yang mengalami wandering, kurang istirahat, perilaku yang diulang-ulang, resistensi dan tergantung(Judy, 2017). Pengetahuan merupakan hal yang sangat penting dalam memberikan perawatan kepada demensia dan dalam memutuskan modalitas terapi yang akan digunakan oleh caregiver, sehingga peningkatan pengetahuan tentang demensia dan gejala-gejala yang menyertainya sangat penting dilakukan (Lau, Chan and Szeto, 2018).

Aktifitas dalam social leisure activity merupakan aktifitas yang biasa dilakukan oleh lansia di rumah. Aktfitas-aktiftas tersebut juga merupakan aktifitas yang dianjurkan sebagai alternatif aktifitas yang dapat dipilih untuk dilaksanakan dirumah. Zoerick (2001) dalam penelitiannya menemukan hasil bahwa leisure activity bermanfaat dalam memberikan stimulasi kognitif lansia demensia, dimana aktifitas yang memberikan rasa nyaman dapat berpengaruh terhadap harga diri dan penguasaan diri. Leisure activity merupakan bagian penting yang memberikan kompensasi positif pada lansia demensia yang mengalami kehilahan hubungan sosial dan menderita penyakit fisik maupun psikologis, aktifitas yang bersifat rekreasional sangat berpengaruh dalam membangun hubungan yang erat dengan lingkungan sosial lansia (Reynolds, 2010). Dalam teori aktivitas dinjelaskan bagaimana kepuasan hidup dan kebahagian pada lansia dipengaruhi oleh tingkat partisipasi dalam lingkungan sosial dan leisure activity, aktifitas fisik dapat menstimulasi fungsi kognitif lansia Demensia, lansia sehat, dan mampu mengurangi gejala neuropsikiatri. (Zhang et al., 2017).

Social leisure activity merupakan aktifitas yang mudah, murah dinilai efektif dan efisien dalam mengatasi permasalahan pemberian aktifitas kepada lansia dengan demensia. Aktifitas ini tidak memerlukan tingkat finansial yang tinggi, aktifitas yang umum dilakukan pada masa sekarang, dan merupakan aktifitas yang sudah menjadi kebiasaan sehari-hari. Prinsip utama dalam memberikan social leisure activity adalah aktifitas dilaksanakan untuk mengisi waktu luang, dengan mengedepankan hubungan sosial dengan lingkungan sekitarnya sehingga harus dilaksanakan bersama-sama dengan caregiver, keluarga, atau orang sekitar rumah. Bahwa dengan melakukan aktifitas bersama lansia demensia secara tidak langsung dipaksa untuk masuk dalam suasana baru. Lansia dalam suasana yang baru tersebut dirangsang untuk merasakan kembali kehadiran orang terdekat atau berarti dalam hidupnya untuk membangun atau meningkatkan hubungan yang positif. Selain itu lansia juga dirangsang untuk kognitifnya agar menjadi lebih baik.

\section{KESIMPULAN}

Intervensi social leisure activity dapat menurunkan risiko wandering klien lansia. Social leisure activity dapat menurunakan risiko wandering bila dilakukan secara rutin dan berkesinambungan. Social leisure activity sangat efektif dilaksanakan karena mudan dan biasa dilakukan oleh masyarakat, serta efisien karena tidak membutuhkan biaya yang tinggi.

\section{DAFTAR PUSTAKA}

Alan, J. L. (2017). Dementia reported missing: use of google news to estimate frequency and mortality of critical wandering in the united state.

Association, A. (2017). 2017 Alzheimer's disease facts and figures. Alzheimer's and Dementia, 13(4), 325-373. https://doi.org/10.1016/j.jalz.2017.02.0 01

Barnard-Brak, L., Richman, D. M., \& Owen, D. C. (2018). Assessing wandering risk among individuals with Alzheimer's disease and dementia: A pilot study. Psychogeriatrics,

$1-5$. https://doi.org/10.1111/psyg.12336 
Baumgart, M., Snyder, H. M., Carrillo, M. C., Fazio, S., Kim, H., \& Johns, H. (2015). Summary of the evidence on modifiable risk factors for cognitive decline and dementia: A population-based perspective. Alzheimer's and Dementia, 11(6), 718-726. https://doi.org/10.1016/j.jalz.2015.05.0 16

Bayu, P. A. (2017) 'The Effect of Religious Intervention on Depression and Quality of Life among Indonesian Elderly: A Quasi-Experimental Study'.

Brittain, K., Degnen, C., Gibson, G., Dickinson, C., \& Robinson, L. (2017). When walking becomes wandering: representing the fear of the fourth age. Sociology of Health and Illness, 39(2), 270-284. https://doi.org/10.1111/14679566.12505

DY Suharya (2017). Alzheimer Di Indonesia, Perkembangan Dan Tantangan. Yogyakarta: Republika

Gagliardi, C., Marcellini, F., Papa, R., Giuli, C., \& Mollenkopf, H. (2010). Associations of personal and mobility resources with subjective well-being among older adults in Italy and Germany. Archives of Gerontology and Geriatrics, $\quad 50(1), \quad 42-47$. https://doi.org/10.1016/j.archger.2009. 01.007

Judy, A. (2017). Creative ways to care: Strategies for carers of people living with dementia-an evidence-based education program dor family and freiend carers to use activities and diversional strategies at home. Health Care Service.

Kwak, Y. T., Yang, Y., \& Koo, M.-S. (2015). Wandering in Dementia. Dementia and Neurocognitive Disorders, 14(3), 99. https://doi.org/10.12779/dnd.2015.14.3 .99

Lau, W. M., Chan, T. Y., \& Szeto, S. L. (2018). Effectiveness of a home-based missing incident prevention program for community-dwelling elderly patients with dementia. International Psychogeriatrics, (May), 1-9. https://doi.org/10.1017/S10416102180 00546

Lin, C. Y., Wang, J. Der, Pai, M. C., \& Ku, L.
J. E. (2017). Measuring burden in dementia caregivers: Confirmatory factor analysis for short forms of the Zarit Burden Interview. Archives of Gerontology and Geriatrics, 68, 8-13. https://doi.org/10.1016/j.archger.2016. 08.005

MacAndrew, M., Fielding, E., Kolanowski, A., O’Reilly, M., \& Beattie, E. (2017). Observing wandering-related boundary transgression in people with severe dementia. Aging and Mental Health, 21(11), 1197-1205. https://doi.org/10.1080/13607863.2016 .1211620

Moyle, W., Jones, C., Murfield, J., Thalib, L., Beattie, E., Shum, D., Draper, B. (2018). Effect of a robotic seal on the motor activity and sleep patterns of older people with dementia, as measured by wearable technology: A cluster-randomised controlled trial. Maturitas, 110(December 2017), 1017.

https://doi.org/10.1016/j.maturitas.201 8.01 .007

Olley, R., \& Morales, A. (2018). Systematic review of evidence underpinning nonpharmacological therapies in dementia. Australian Health Review, 42(4), 361369. https://doi.org/10.1071/AH16212

Prince, M., Wimo, A., Guerchet, M., Ali, G., Wu, Y. \& Prina, M. (2015). The Global Impact of dementia: an Analysis of prevalence, incidence, cost and trends. Alzheimer's Disease International.

Qiang, L., Weichao, Z., \& Weilan, W. (2018). Detecting dementia-related wandering locomotion of elderly by Leveraging Active Infrared Sensors. Scientific Research. https://doi.org/10.4236/jcc.2018.65008

Ray, K. D. and Mittelman, M. S. (2017) 'Music therapy: A nonpharmacological approach to the care of agitation and depressive symptoms for nursing home residents with dementia', Dementia, 16(6), pp. 689-710. doi: $10.1177 / 1471301215613779$.

Reynolds, F. (2010). "Colour and communion": Exploring the influences of visual art-making as a leisure activity on older women's subjective wellbeing. Journal of Aging Studies, 24(2), 
135-143.

https://doi.org/10.1016/j.jaging.2008.1

0.004

Traynor, V., Veerhuis, N., Johnson, K., Hazelton, J., \& Gopalan, S. (2018). Evaluating the effects of a physical activity on agitation and wandering (PAAW) experienced by individuals living with a dementia in care homes. Journal of Research in Nursing, 23(2$3)$, $125-138$. https://doi.org/10.1177/174498711875 6479

Volicer, L., Van Der Steen, J. T., \& Frijters, D. H. M. (2013). Involvement in activities and wandering in nursing home residents with cognitive impairment. Alzheimer Disease and Associated Disorders, 27(3), 272-277. https://doi.org/10.1097/WAD.0b013e3 1826d012e

Zhang, W., Feng, Q., Lacanienta, J., \& Zhen, Z. (2017). Leisure participation and subjective well-being: Exploring gender differences among elderly in Shanghai, China. Archives of Gerontology and Geriatrics, 69, 45-54. https://doi.org/10.1016/j.archger.2016. 11.010 